\title{
BRITISH MAMMALS
}

\section{THE MAMMALS OF LAKELAND}

\section{By Ernest Blezard}

The Faunal Area of Lakeland comprises Cumberland, Westmorland and Lancashire North of the Sands. Relatively well defined, mainly by sea coast and lengthily by the Pennines, it originates in the central mountain mass cradling many broad waters, which is the Lake District of universal appeal. This lake and fell region and its surroundings extending to about two-thirds of the whole area, is the Lake District National Park, the first park to be designated by the National Parks Commission. During the present century, the National Trust has acquired many properties with a view to preserving their natural amenities. On the other hand, towns and villages have spread apace, following upon all those human enterprises which, through the ages, have transformed the land into its present state. Besides agriculture there are, for example, the shecp-rearing industry, with its effecton hill vegetation and bygone mining activities to which so much of the native tree growth was sacrificed. Now the work of the Forestry Commission is bringing a new aspect to parts high and low between the northern and southern limits of the area. Some older features remaining to be considered in relation to the wild animal life are the varied tree plantations on the landed estates, together with well wooded river valleys and still extensive birch and pine-fringed peat mosses. Sweeping though they have been down the centuries, the surface changes in Lakeland have had far from a completely adverse effect on the native mammals. While for some the fells have perhaps meant salvation, there are two of the most ancient residents which, from mere survival, have rather astonishingly increased and spread.

At the end of the eighteenth century, the fells between Patterdale and Mardale became the one great stronghold of the indigenous red deer. It was then that the chases of Inglewood and Whinfell were disforested, and the Crown Forest of Coupland or Ennerdale lost the last members of its herds. The present Martindale deer, as they are generally known, roam the dales and fell shoulders to the heights of Figh Street and to Place Fell above Ullswater. Lighter in build as they may be-though twelve-pointers or royals do occur among them-they are the lineal descendants of the ancient race whose much more massive antlers are found every now and again in river beds or estuarine sands. Red deer ranging between Gowbarrow and Helvellyn, on the other side of Ullswater, are considered to have sprung from 
Martindale stock. Stags in rut have been known to swim across the lake to reach the hinds in Gowbarrow.

Furness Fells and their red deer broke into the news a few years ago causing astonishment at the numbers of the animals there. Original survivors as well as strays from Martindale could account for them, together with a number let loose by the Oxenholme IIunt. All together, they may be far short of the Martindale strength, but a hundred of them have been estimated in limited country between Windermere and Coniston Water.

The fox, found almost everywhere, is yet strongly characteristic of the fells which formerly were believed to have their own "greyhound" race, now just as surely believed" to be gone. However that may he, foxes still abound, something like a hundred being killed in a season by each of the fell packs of hounds, which operate very much in the interests of the flockmaster and shepherd. The Lake Fells, the Pennines and the wastes towards the Borderland all alike are the fox's domain. Even the saltmarshes know the fox, where it seeks the lost carcases of wildfowl ; the low-lying peat mosses are decidedly favoured haunts. Not so long ago, I spent two evenings watching a litter of thirteen cubs which were denned only a quarter of a mile away from a litter of nine. And that was in the low country.

So long as the old forests existed, it is possible that the pine marten had a wider distribution than it has to-day. In the fell country, it still frequents the trees or may have partially reverted to them, while continuing to maintain its retreats in the crags. The rock ranges most favoured are birch and rowan grown and have a sunny aspect. Though elusive and sparse, the "mart" of the dalesman is known in places from Dunnerdale northward to the Skiddaw group and recent reliable report comes of its appearance in the east of Westmorland. Very usually, no more than footprints in snow, foil or other traces point to its presence. On a high crag in Borrowdale I came upon an indicator which further conveyed an ascribed habit. This find was the skull of a sheep with the thin bone finely bitten away to allow the brains to be licked out of the case. It can perhaps safely be said that the pine marten in Lakeland is holding its own.

The two mammals that have forged ahead out of decline are the badger and the roe deer which in the past have both been described as extinct here, or nearly so. They link together by their recent great increase over much the same period and by frequently sharing the same haunts. Some few badgers must have escaped the fierce persecution and time of head money in the seventeenth and eighteenth centuries, but it is only within 
the course of the present century that "brock" has become the common resident he is to-day. There are now occupied setts throughout the area in all types of countryside affording sandy or light soil for ready tunnelling and others in craggy haunts, up to some altitude on the fells.

Roe deer certainly lingered in the wilder northern parts of Cumberland during the long years of low population and undoubtedly in the natural woodlands of Furness and Cartmel as well. Two different kinds of later tree growth contributed to the revival of the species as also did its wandering propensities. First the expanses of birch scrub which replaced the tall timber felled in 1914-18, provided the harbourage of earlier times; then the roe took quickly to the new State Forests of conifers and multiplied exceedingly in their shelter. Roe and red deer run together in High Furness and again in Gowbarrow which, moreover, claims all the three familiar species, including a few free-ranging fallow deer. Wanderers of this last species occasionally turn up in Greystoke Park, whose original 6,000 acres of grassland have in part been planted by the Forestry Commission. The park herds of fallow deer remaining are the old established one at Holker in Cartmel and a smaller one at Armathwaite by Bassenthwaite Water.

Unlike the pine marten, the once commoner polecat does not seem to have survived ; not in any part of the area, high or low. Far off are the days when the handloom weavers of Carlisle regularly celebrated their week-ends by going off with scratch packs of dogs to hunt foumarts in the rough country and mossland, to the west of the city. Polecats thought seen in late years, including one by myself, have all had doubt cast on their genuineness. Supposed polecats, trapped or shot in several districts, have proved every one to be feral ferrets of the big brown strain. Of the martens' smaller relatives, the stoat and the weasel, the former is much the more common and goes higher on the fells.

A multitude of waters, the lakes, tarns, rivers and their feeders bring the otter into general distribution. Its travellings take it to the coast and to the high fell becks and it may lie up for the day in unexpected places, such as a hedge bottom on farmland or the rush fringe to a moss pool. I have watched two otters at evening fishing in tidal water, and two on a sunny afternoon disporting in a small tarn, each time close to a village. Widespread, too, are the small aquatic mammals, the water vole and the water shrew, respectively numerous and apparently uncommon. So far as it has been traced, the shrew ascends to at 
least a thousand feet. The habitat of the water vole, typically a lowlander, includes nearly any kind of small watercourse with contents fresh or brackish. The black variety of this vole, so long classed as rare, I know to occur in and near Carlisle and last saw in a Solway saltmarsh creek.

An old belief that the brown hare increases as the rabbit declines, or that the two do not go well together, is not entirely substantiated. A notable increase in hares was already pronounced before the arrival of myxomatosis to sweep the rabbit population away. From my own garden fence, six or eight hares are regularly visible in a meadow where, for years, a single one would have been an exceptional sight. Rabbits now show a little recovery in many districts. The mountain hare in Lakeland is limited to a few individuals on the wild northern moors. It originates in stock introduced at different times on either side of the Scottish Border.

Regarding the woodland rodents, the red squirrel has declined to a marked extent and the dormouse evidently become sparser in the southern coppices. The native squirrel was losing its hold before the wholesale felling of woods and plantations so that its disappearance is not simply due to a shrinkage of habitat. It continues in the mixed woods around the lakes, in the pines of the mosslands and, for particular mention, in the old conifers of the former chase of Whinfell. The grey squirrel has been killed at least four times in Westmorland since 1944 and credibly reported twice in the neighbourhood of Carlisle.

The hedgehog remains abundant despite the fact that no mammal meets death more frequently on the roads. Measures are continually being taken against the mole yet it contrives to recur in plenty, occasionally working its way far up on to the fells. The abundant field vole, a common prey of some other mammals and of a variety of birds, overruns the young conifer plantations where it attracts the short-eared owl. This vole, as it occurs at 1,500 feet or more on the fells, inclines to be greyer and finerhaired in the coat than is the lowlander. No more need be said of the rodent enemies in chief than that the black rat apparently last lingered in the Pennine region and Low Furness, before it finally disappeared.

Unlike the common shrew and the long-tailed field mouse, both common, the very small mammals, the bats in particular, are not at all well known. The pigmy shrew and the bank vole, have been taken in several districts, but wide gaps may need to be filled in their distribution. Among the prey of hawks and owls in Cumberland, I have found pigmy shrew captured by 
kestrel, water shrew by kestrel and tawny owl; bank vole by the same two birds and by barn owl.

Seven species of bats only have been recorded and more attention to bats is needed. Within a twelve mile radius of Carlisle I have discovered that the common bat is by no means the pipistrelle, but the whiskered bat. In fact, no more than three pipistrelles out of many bats, have ever come to hand. The same part of the area has produced two examples of the long-eared bat which is also known for Westmorland by one specimen from Windermere, the first county record, and one from Mardale. There is a comparatively recent record of Natterer's bat from Alston in the Cumberland Pennines. The noctule has become common in this county in late years; it is now frequently to be seen in many places and not usually alone, in fact it regularly appears over my home garden in strong, direct flight. From deer to bats, this consideration of the land of mammals happily does not all run to a loss account.

\section{REVIEW}

Kingdon of tile Beasts. Text by Julian Huxley. Photographs by W. Suschitzky. Thames and Hudson, London, 1056. Price 50s.

Nobody would question Dr. Huxley's eminence in the scientific world or Mr. Suschitzky's in the photographic. Hiere we have the ingredients of a good mixture and there has indeed been a happy blending between the work of the learned scientist and the artist in photography. Not only are the text and the illustrations each excellent, but the integration between them is complete.

Of course, if you are seeking a book on general natural history or even on mammals, for only mammals come into the Kingdom of Beasts, you will not find it here. The book is built around the photographs and though every "Order" except the Cetacea and the difficult Dermoptera has its representatives, and the scientific name of each animal mentioned is given, there is no further classification.

The book starts with a short general survey of mammals, including prehistoric mammals, prehistoric man, and evolution. Dr. Huxley expresses the opinion that the transcending importance of man's brain in recent evolution is due to all other lines of advance having reached their limit in the Pliocene epoch, perhaps five million years ago. Is it not possible or even likely 